\title{
諸種腎疾患の病態生理に関する研究
}

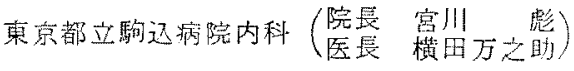

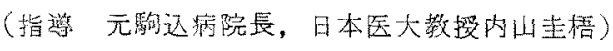 \\ 山辺亘
}

\section{STUDIES ON THE PATHOLOGICAL PHYSIOLOGY OF RENAL DISEASES}

\author{
Akira YamaBe \\ Department of Internal Medicine, the Komagome Hospital, Tökyō \\ (Director: Hyō Miyakawa, Chief of the Department: Mannosuke Yokota) \\ Directed by Keigo Uchiyama \\ (Exdirector of the Komagome Hospital \\ Professor of Nippon Medical College)
}

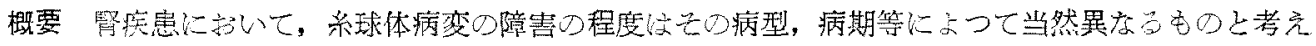

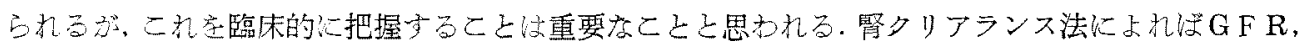

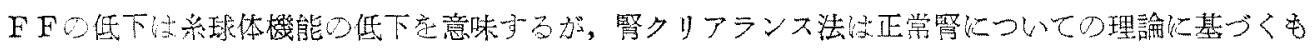

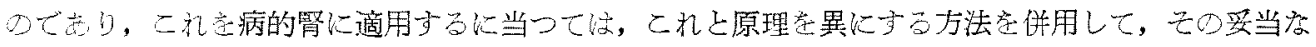

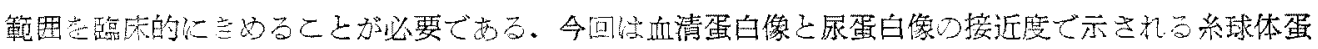

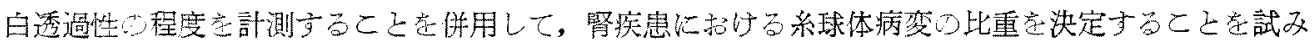

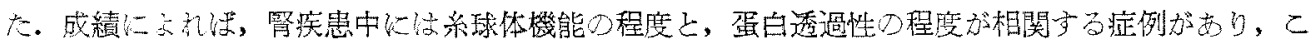

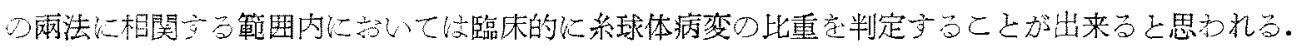

\section{I 緒言}

Van Slyke らによつて提唱され, Smith ${ }^{1)} ら$ によつて確立された腎クリアランス法渻血嶈流 量，系球体濾過值等個々の靔機能を数量的に測定 するここが可能となり，孯機能の解明は飛躍的に 発展を遂げるに至つた。しかし腎クリアランス法 は正常腎についての理論に基つくものであり，病 的腎についての腎機能の解䣋にはな打多くの疑点 を残している。元礼沛，堅クリアランス法を病 的㹂に適用するに当つては，これと原理を異にす

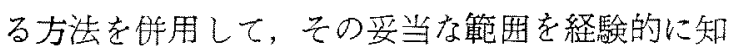
る必要䜑ある。

一方，堅疾患に認如らる尿蛋白は，現在血清
蛋白に由来される2334)ことは明らかな事箺とさ れている。そして一部は尿細管における蛋白の再 吸收が関与するが8) 11)，多くは系球体毛細管の 透過性の亢進が尿蛋白の成因である゙56) れている，それ故，尿蛋白像が血清蛋白像に援近 を示すことは，糸球体蛋白透過性の克進を意味 し，このことは系球体機能の低下とも関係するも のと考えら机る。

今回，私は謷クリアランス法による血行動態で 示される糸球体機能の測定と，血清沓蛋白像の接 近度で示される系球体蛋白透過性の測定を併用守 ることにより，諸種腎疾患に打ける系球体病变の 比重を臨床的に制定することを試み，いさっ加知 
見を得たので報告する。

\section{II 研究対象並びに方法}

\section{1) 封象}

昭和30年以来当院に入院した患者45例について 行なつた、腎クリアランス法の蚞查回数は総数 121回, 蛋白像の検查回数は 118回でその内の大多 数の例では 2 回以上その経過追求した。疾患别 では急性腎炎17例，慢性腎炎13例，ネフローゼ症 候群 8 例，Kimmelstiel-Wilson 症候群 2 例， 惡性腎硬化症 5 例である。急性腎炎, 慢性腎炎及 びネフローゼ症候群では大多数の例では40才以下 の者を対象乙し，殊に急性腎炎では10才以下の小 睍4例が含まれている。同一症例についての観察 期閒は最高 3 年 5 月に及んだ。以上の症例では入 院後主として安静拐よび食䭒療法を行ない，その 他は対症療法に止めた。

2) 検查方法

1. 緊クリアランス

腎血漿流量（RPF）注バラアミ)馬泉酸ソー ダ，糸球体滤過值（GFR）はチ才硫酸ソーダを

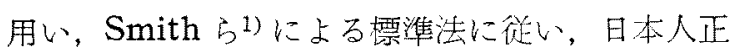
常体表面積 $1.48 \mathrm{~m}^{2}$ で補正して求めた。

2. 血嶈並びに尿蛋白像

血漿蛋白の定量はPulfrich浓㴆屈折計を用い, 一部は日立蛋白計を使用した。血獎蛋白像の分析 に汢PH 7.801/20M. 燐聡緩衡液で蛋白濃度が約 3 \%になるように稀秎し，50番七ロハン袋に入れ， 大量の上記緩衡液に浸し承空中で24時間透析後, 日立整作所 Tiselius 淩置を用い，泳動㣪その下 降脚について計測し，各分屏の相対濃度を計算し た。尿蛋白の定量は末吉法によつた，尿蛋白像の 分析には，24時間蓄尿を滤紙にて濾過し，大量の $0.4 \%$ 食塩液で透析後，蛋白濃度が約 $3 \%$ になる まで減压濃縮を行ない，濃縮後血漿と同様に行な つた.

3. 血清尿蛋刍像の接近度

血清尿蛋白像の接近度を測定する手段として， 著者は Tiselius の装置で測定した上記の蛋白像

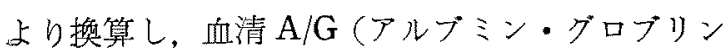

比）及び尿 $A / G$ を求めた。そして血清 $A / G$ の 值で原 $A / G$ の值を除した。

すなわち， $\frac{\text { 泉 } \mathrm{A} / \mathrm{G}}{\text { 血清 } \mathrm{A} / \mathrm{G}^{-}}=\mathrm{A} ・ \mathrm{I}$ を求めた。

著者は一応この值を $\mathbf{A} ・ \mathrm{I}$ (Approach Index) と呼标する。A・Iが 1 に接近すれば，尿の蛋白 像は血清蛋白像に接近を示すこと〉なる。

4. $\min \mathrm{G}_{\text {prot, }} \mathrm{C}_{\text {prot, }} \mathrm{C}_{\text {pro }} / \mathrm{GFR}$

i) $\min G_{\text {prot. }}$

Chinard6)5)らによる最小系球体蛋白濃度算 出した。

$\min \mathrm{G}_{\text {prot. }}\left(=\mathrm{U}_{\text {prot. }} \mathrm{V} / \mathrm{GFR} \times 100\right) \mathrm{mg} / 100$ $\mathrm{ml}$

$$
\begin{aligned}
& \mathrm{G}_{\text {prot. }}=\text { 系球体中滤液蛋白濃度 } \\
& \mathrm{U}_{\text {prot. }}=\text { 尿中蛋白濃度 } \\
& \mathrm{V}=1 \text { 分間尿量 }
\end{aligned}
$$

ii) $\mathrm{C}_{\text {prot. }}$

蛋白クリアランスは次式にて求めた。

$$
\begin{aligned}
& \mathrm{C}_{\text {prot. }}=\mathrm{U}_{\text {prot. }} \mathrm{V} / \mathrm{P}_{\text {prot. }} \\
& \mathrm{U}_{\text {prot. }}=\text { 尿中蛋白濃度 } \\
& \mathrm{V}=1 \text { 分間尿量 } \\
& \mathrm{P}_{\text {prot. }}=\text { 血清蛋白濃度 }
\end{aligned}
$$

iii) $\mathrm{C}_{\text {prot. }} / \mathrm{GFR}^{6)}$ 求めた。

5. その他の程查法

尿有形成分の算定はお〉兑称 Addis の原法 によつた。血中コレステロールの定量の大多数 はZak, Henly 法によつた。眼底所見は Keith Wagner の分類に従つた.

\section{III 研究成績}

1) 正常值

1. 腎》リアランス

7 例の正常人 (平均年命13才) の腎》リアラン 不值の平均は下記の如くであつた。

$\begin{array}{lc}\text { RB F } & 1025.9 \pm 55.3 \mathrm{ml} / \mathrm{min} \\ \text { R P F } & 623.0 \pm 32.5 \quad \prime \prime \\ \text { GFR } & 143.3 \pm 5.5 \quad \prime \prime \\ \text { F F } & 0.22 \pm 0.004\end{array}$

2. 血装蛋罒像

15例の正常人の血嶈蛋白像の平均值は, 次の如 くであつた。 


\section{T.P $\quad 7.8 \pm 0.04 \mathrm{~g} / \mathrm{dl}$}

Alb. $\quad 64.0 \pm 0.57 \%$

$\begin{array}{lr}\alpha & 5.6 \pm 0.18 \prime \prime \\ \beta & 9.7 \pm 0.16 \prime \prime \\ \phi & 5.7 \pm 0.18 \prime \prime \\ \gamma & 15.0 \pm 0.44 \prime \prime\end{array}$

\section{3. 康蛋白像}

本研究に扔いては蛋白像の分析手段として Tiseliusの装置を用いたので，技術上から正常人の 尿蛋白の分析は行な之なかつたが，溜紙電気泳 動法による Mc Garry ら7)，Rigas らの研究によ れば，1日の尿蛋白量は100mg以下で，A／G注 0.5〜0.65であるという。

2）急性䒜炎

\section{1. 被検症例}

この項で取报つた急性腎炎は，それまでに腎 炎，高血圧，心疾患の既往がなく急に浮腫，血圧 の上昇，蛋白尿，血尿等のいずれかの症状老以て 来院した中で，初笔症状より抢よそ1力月以内に 検查を開始したものである。

2. 成續

腎機能の概要は表 1 に示した。血整尿蛋白像法 表 2 に示した。一般臨床娭查成績の概要は表 3 に

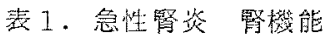

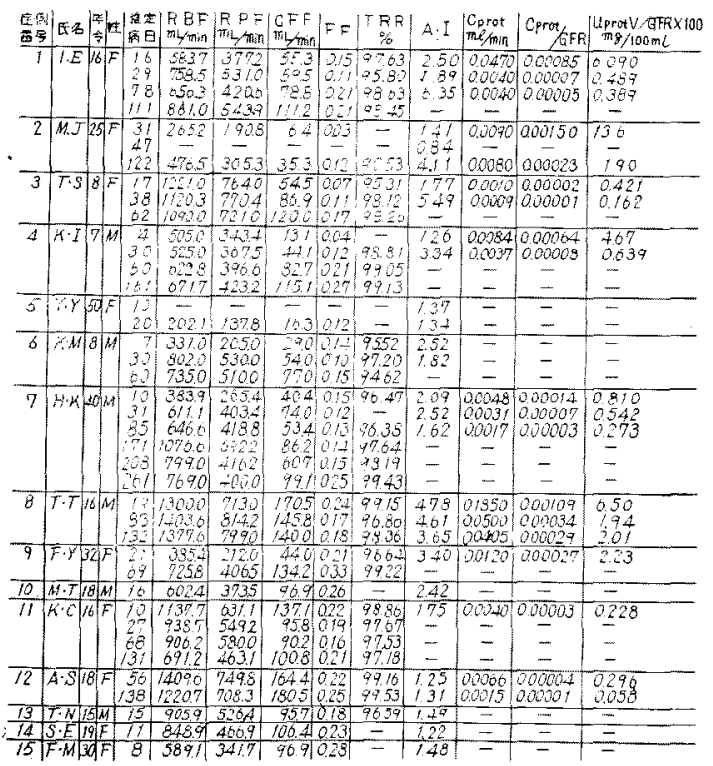

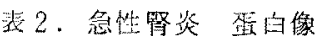

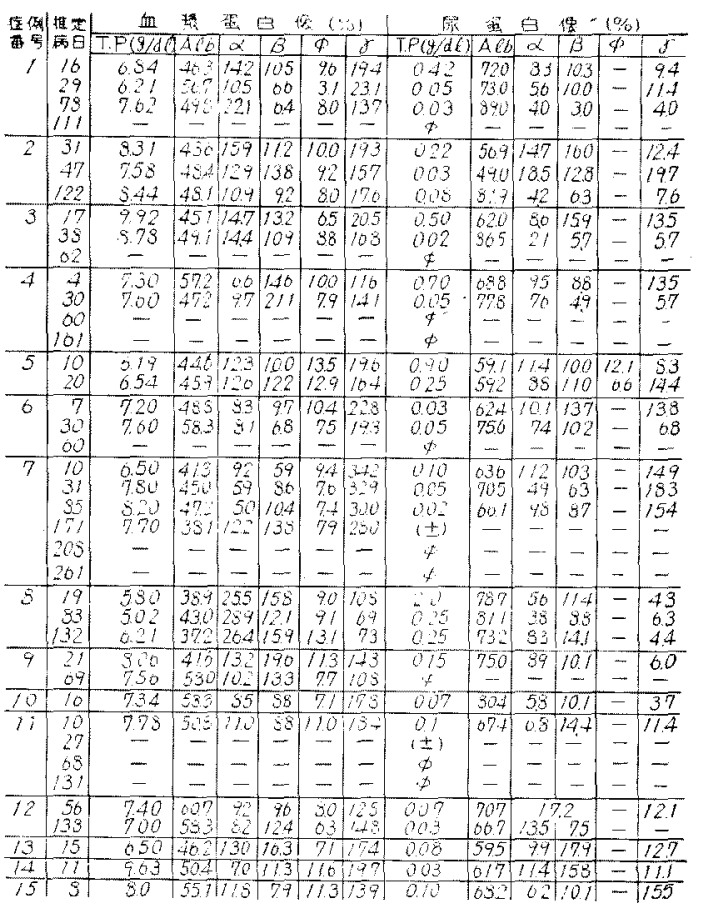

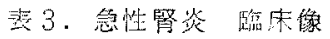

\begin{tabular}{|c|c|c|c|c|c|c|c|c|}
\hline & 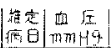 & 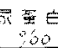 & $\frac{R}{2}$ & 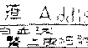 & (10) & 残秘 & to & \\
\hline & 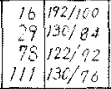 & $\begin{array}{l}\frac{12}{25} \\
0.3 \\
9\end{array}$ & $\begin{array}{r}00 \\
10,0000 \\
15740 \\
150\end{array}$ & $\begin{array}{r}1+1 \\
27550 \\
2525 \\
\phi\end{array}$ & $\begin{array}{c}1+1 \\
6500 \\
70 \\
\phi\end{array}$ & $\begin{array}{l}320 \\
420 \\
210 \\
245\end{array}$ & $\left.\begin{array}{l}+1 \\
1+1 \\
(\rightarrow) \\
(\rightarrow)\end{array}\right]$ & ; \\
\hline & $\begin{array}{l}31 / 40120 \\
47 / 46 / 0\end{array}$ & 22 & $\begin{array}{l}55 \\
57 \\
78\end{array}$ & 130 & ${ }_{0}^{\prime}$ & $\begin{array}{l}35.0 \\
41.0 \\
180\end{array}$ & $\begin{array}{l}0+1 \\
(-1) \\
-1\end{array}$ & 不明 \\
\hline 3 & 10 & $\begin{array}{l}85 \\
82\end{array}$ & 90000 & 4 & $\frac{4}{72}$ & $\begin{array}{l}56.0 \\
440\end{array}$ & $(+1)=$ & 治溧 \\
\hline & 6213998 & $\pi 0$ & 60 & & ++1 & 50 & $(-)$ & \\
\hline & $30 \mid 00 \%, 0$ & 05 & (H) & $1+1$ & $+?$ & 330 & (t) & 治政 \\
\hline & 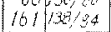 & $\phi$ & $i+1$ & \pm & $\phi$ & 250 & $(-1$ & \\
\hline & $10140 / 10$ & 70 & $\infty$ & $i+1$ & $(+)$ & 500 & $(+):=$ & 㳂淇 \\
\hline & $7 / 142 / 90$ & 0.3 & $\frac{11}{(-1)}$ & +1 & $\frac{1}{+1}$ & 420 & (1) $]$. & $T_{0}$ \\
\hline & 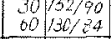 & 05 & (t) & $\Phi$ & $\left(\begin{array}{l}( \pm) \\
\phi\end{array}\right.$ & $\begin{array}{l}350 \\
230 \\
\text { and }\end{array}$ & $(-))^{(t)}$ & tor \\
\hline & 10180990 & 100 & 177 & 23700 & th & 020 & (i+i) & \\
\hline & $351.50 \% 72$ & & 9925 & (土) & 8 & 300 & $(-1)$ & 治然 \\
\hline & $208390 / 50$ & $\phi$ & 36650 & 250 & 840 & 20.0 & $i=1$ & \\
\hline & $26 / / 32 / 84$ & & & & & 23.0 & $(-1)$ & \\
\hline & $\begin{array}{l}791 / 14 / 90 \\
83 / 126 / 70\end{array}$ & 200 & $\begin{array}{r}7500 \\
25600\end{array}$ & woo & $\begin{array}{r}7500 \\
65\end{array}$ & $\begin{array}{r}315 \\
250 \\
310\end{array}$ & $\left(\begin{array}{c}+1 \\
i+1\end{array}\right)$ & 未治 \\
\hline & $21 / 120,09$ & 15 & . & 8 & $(i t)$ & 400 & +1 & F。 \\
\hline & 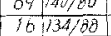 & $\psi$ & $\frac{-4}{i+1}$ & & -1 & & $t-1$ & 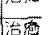 \\
\hline & $10 / 132 / 162$ & 1.0 & & 437 & $\phi$ & 27.4 & (i+i) & \\
\hline & {$\left[\begin{array}{l}27 \\
08 \\
0\end{array} 1140\right.$} & \pm & $\begin{array}{l}33500 \\
340\end{array}$ & 1680 & $\dot{\phi}$ & 28.0 & 证 & 接证 \\
\hline 12 & 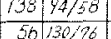 & $\phi$ & & $\phi$ & 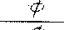 & & -1 & \\
\hline 13 & $\frac{135}{15} 10096$ & 0.3 & & & $\phi$ & & & 治㗪 \\
\hline & $\frac{1112}{1112}$ & 100 & $i \pm$ & (I) & $-\phi$ & & & 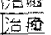 \\
\hline & & & & & & & ii. & 治雪 \\
\hline
\end{tabular}


示した。病日の推定は, 初めての自他覚症状出現 の日を以てした。

急性等炎を脊クリアランス值拈よび血清尿蛋白

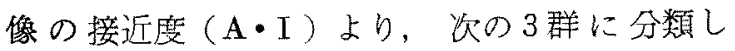
た。

第 1群： 急性餐炎の経過中 G F R, F Fの低 下を諗め，その時期に一致して血清尿蛋白像の接 近を諗めるもの。

第 2 群：急性霄炎経過中F F はあまり低下せ ず，血清㽷蛋白像もそれに一致して接近を示さな いもの.

第 3 群： 急性腎炎経過中F F はあまり低下せ ず，加，血清尿蛋白像は接近を示すもの。

図 1 はこの内第1群に属する症例（症例 1 6) のクリアランス值並びに血清尿蛋白像の接近 度 $(\mathrm{A} ・ \mathrm{I}$ ) の推移を示した。図に見られるごと く, RPFは病日の推移を〉もにあまり変動が認 められないが，GFRは経過中低徝を示す時期が あり，F F注そのとき低下を示した。この時期に 一致してA・Iの1への接近が認好られた。図2 は第 2 群に属する症例（症例 $7 \sim 10$ ）の推移を示

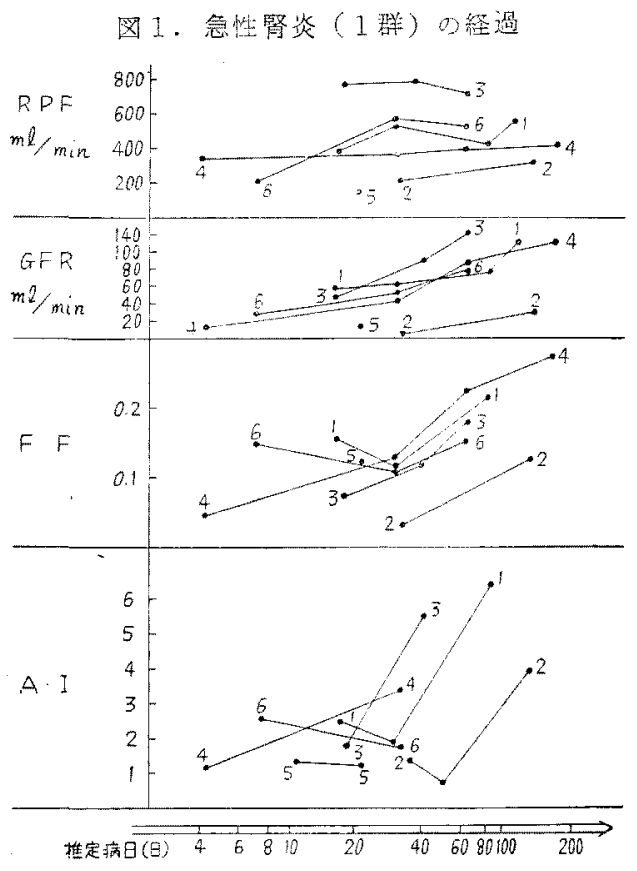

図2.急性腎炎（2 群）の経過

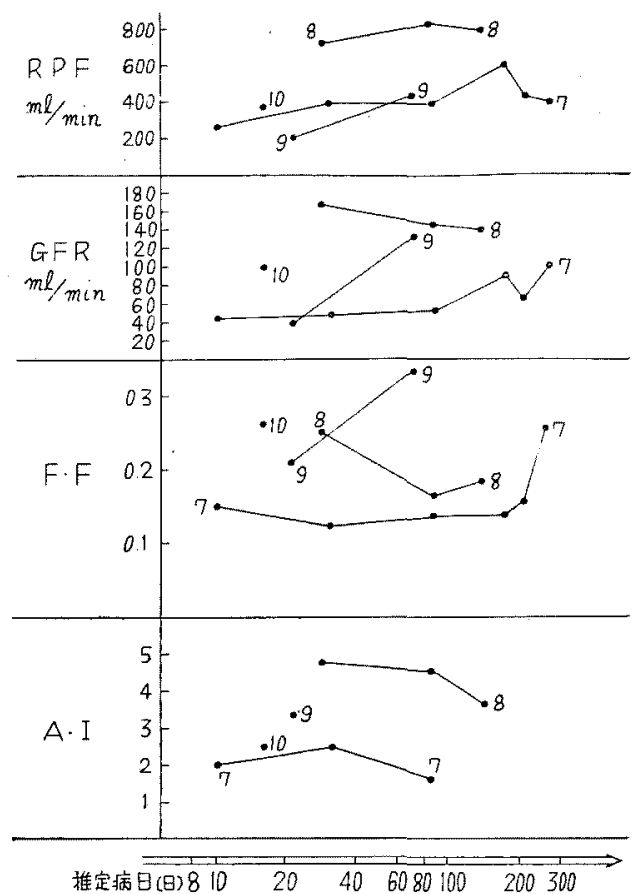

図 3，急性腎炎（3 群）の経過

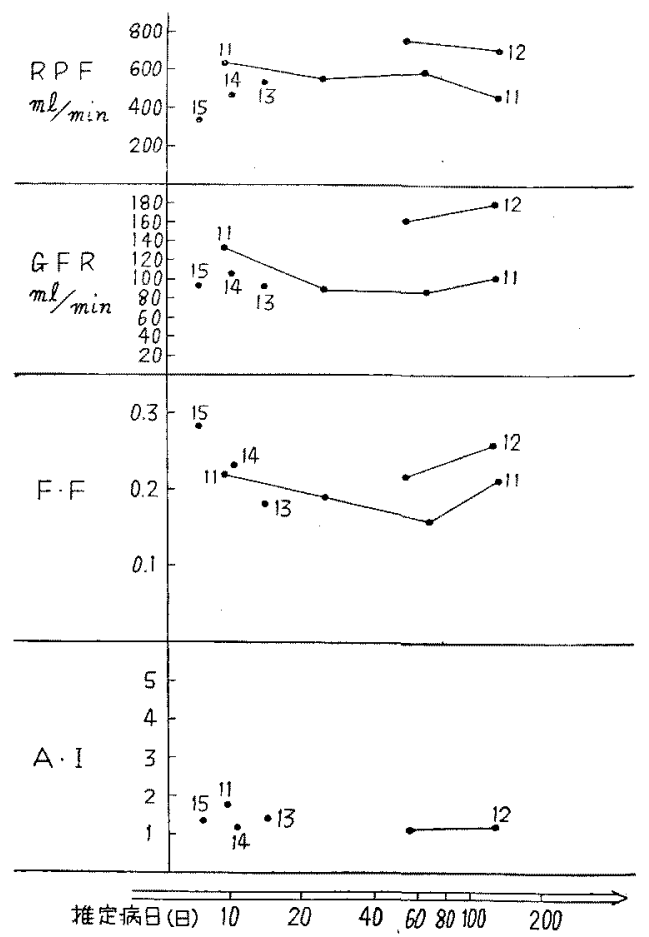




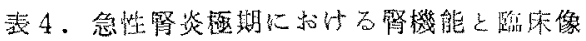

\begin{tabular}{|c|c|c|c|c|c|c|c|c|c|c|c|c|c|c|}
\hline & & & 照 & 1) $p$ & $\because 7$ & & & & & 浩 & & & & \\
\hline F & 正 & 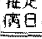 & $\mathrm{R} B \mathrm{~F}$ & RPF & $G F R$ & $F F$ & A.I & 系面赫 & 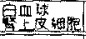 & $\mathrm{P}$ 枉 & itil $\sqrt{t}$ & 整 & 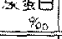 & 浔霾 \\
\hline 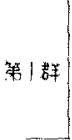 & $\begin{array}{l}1 \\
2 \\
3 \\
3 \\
4 \\
5 \\
0\end{array}$ & $\begin{array}{r}29 \\
37 \\
17 \\
4 \\
20 \\
30\end{array}$ & $\begin{array}{r}758.5 \\
265.2 \\
1227.0 \\
505.0 \\
202.0 \\
337.0 \\
\end{array}$ & $\begin{array}{l}377.2 \\
190.8 \\
764.0 \\
343.4 \\
157.8 \\
205.0\end{array}$ & $\begin{array}{r}59.5 \\
6.4 \\
54.5 \\
73.1 \\
10.3 \\
29.0\end{array}$ & $\begin{array}{l}0.11 \\
0.03 \\
0.07 \\
0.04 \\
0.12 \\
0.10\end{array}$ & $\begin{array}{l}1.89 \\
1.49 \\
1.77 \\
1.26 \\
1.34 \\
1.82\end{array}$ & 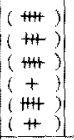 & $\begin{array}{l}(+) \\
(+) \\
(+) \\
(+) \\
(+) \\
( \pm)\end{array}$ & $\begin{array}{c}(+) \\
1+1 \\
6 \\
(+) \\
(+) \\
\pm\end{array}$ & $\begin{array}{l}192 / 100 \\
100 / 102 \\
138 / 94 \\
140 / 90 \\
160 / 00 \\
15 \% / 90\end{array}$ & $\begin{array}{l}42 \\
35 \\
56 \\
50 \\
42 \\
35\end{array}$ & $\begin{array}{l}0.5 \\
2.2 \\
0.5 \\
7.0 \\
2.5 \\
0.5\end{array}$ & $\begin{array}{l}(t+) \\
(+) \\
(t) \\
(+) \\
(+) \\
1+)\end{array}$ \\
\hline 平的 & & & 574.1 & 334.7 & 29.8 & 0.078 & 1.58 & & & & 154,90 & 43,31 & 2.64 & \\
\hline 第2群 & $\begin{array}{l}7 \\
8 \\
9 \\
10\end{array}$ & $\begin{array}{l}10 \\
19 \\
21 \\
18\end{array}$ & $\begin{array}{r}383.9 \\
1300.0 \\
385.4 \\
6024 \\
\end{array}$ & $\begin{array}{l}265.4 \\
773.0 \\
272.0 \\
373.5 \\
\end{array}$ & $\begin{array}{r}40.4 \\
170.5 \\
44.9 \\
90.9 \\
\end{array}$ & $\begin{array}{l}0.15 \\
0.24 \\
0.21 \\
0.20\end{array}$ & $\begin{array}{r}2.09 \\
4.78 \\
3.40 \\
2.42 \\
\end{array}$ & 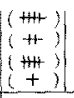 & $\begin{array}{l}(+1) \\
(+) \\
(+) \\
+1\end{array}$ & $\begin{array}{l}(+) \\
(++) \\
\left(\frac{1}{x}\right) \\
\not \varnothing\end{array}$ & $\mid \begin{array}{l}160 / 90 \\
13480 \\
120 / 88 \\
134,88\end{array}$ & $\begin{array}{c}102 \\
37.5 \\
40 \\
32\end{array}$ & $\begin{array}{r}1.0 \\
20.0 \\
1.5 \\
0.7 \\
\end{array}$ & $\left\{\begin{array}{l}(t+) \\
+5 \\
+1 \\
-1\end{array}\right.$ \\
\hline 平沟 & & & 607.9 & 397.01 & 87.9 & 0.275 & 3.17 & & & & $137 / 89$ & 57.41 & 5.8 & \\
\hline 第了群 & $\begin{array}{l}11 \\
12 \\
13 \\
14 \\
15\end{array}$ & $\begin{array}{l}10 \\
56 \\
15 \\
15 \\
8\end{array}$ & $\begin{array}{l}137.1 \\
1409.6 \\
905.9 \\
848.9 \\
589.1\end{array}$ & $\begin{array}{l}031.0 \\
749.8 \\
520.4 \\
406.9 \\
347.7\end{array}$ & $\begin{array}{r}137.7 \\
164.4 \\
95.7 \\
100.4 \\
96.9\end{array}$ & $\begin{array}{l}0.22 \\
0.22 \\
0.18 \\
0.23 \\
0.28\end{array}$ & $\begin{array}{l}1.75 \\
1.25 \\
1.49 \\
1.22 \\
1.48\end{array}$ & 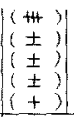 & $\left.\begin{array}{l}( \pm) \\
\pm \\
\pm \\
\pm \\
\pm\end{array}\right)$ & $\begin{array}{l}\varnothing \\
\varnothing \\
\varnothing \\
\varnothing\end{array}$ & $\left|\begin{array}{l}132 / 700 \\
130 / 76 \\
118 / 72 \\
124 / 78 \\
130 \% 80\end{array}\right|$ & $\begin{array}{l}27 \\
30 \\
30 \\
28 \\
23\end{array}$ & $\begin{array}{l}1.0 \\
0.7 \\
0.8 \\
0.3 \\
1.0\end{array}$ & $\begin{array}{l}(+1) \\
\pm \\
-5 \\
-3 \\
-3\end{array}$ \\
\hline 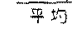 & & & 978.1 & 543.2 & 120.1 & 0.226 & 1.44 & & & & $|727 / 83|$ & 298 & 0.76 & \\
\hline
\end{tabular}

した，図に見られる如くFFは第1群で認められ るような極端な低下は経過中認められず，A・I も一致して 1 に接近するのを認めない。图3壮第 3群に属する症例(症例11〜15) の推移を示した。 图に兒放るようにFF住あまり低下走さず， かつ、A・I注なり1への接近を認めた。

次に臨床所見との関係を見ると，腎资に先行す る感染は第 1 群では全てのものに認めら机た。こ 上に症例 3，402例注猖紅熱発病後に起二つた

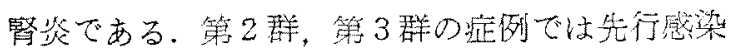
の諰められない症例も㐫つた。呕吐, 頭痛等の症 状注第 1 群の症例で法顕著であり，第 2 群では症 例 7，9にはかなり明らかであつたが，その他の 症例抬上び算了群の症例では目立たなかつた。こ れらの症例の腎㙨能乙臨床所見の概要を, 臨床的 の極期において比較すると表40如くである。第 1 群では，GFRは 6.4 $59.5 \mathrm{ml} / \mathrm{min}$ (平均 29.8 $\mathrm{ml} / \mathrm{min}$ ) で, F F $0.03 \sim 0.12$ (平均 0.078 ) であつた。

A・Iは1.26〜1.89（平均1.58）で血清尿蛋当 像のかなりの接近を認めた。この群ではいずれも 肉腿的索い儿显微鏡的血尿が目立方，かなりの

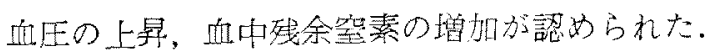
沓蛋白沬 0.5 7\% ( 壮均2.64\%) で，いずれの 症例においても浮腫が見られた。
第2 群の症例ではRPFに較べてGFRはあま 门低下せず，FFは0.24〜0.15（平均 0.215）で あつた。A・I注2.09〜4.78（平均3.17）で血清 录蛋白像の接近は認内られ劣い。この群ではいず れの症例においても，第 1 群の症例と同橔に肉腿 的ないしは顕微鏡的血尿，白血球，腎上支細胞， および円柱の增加加多々の例で認められた。血王

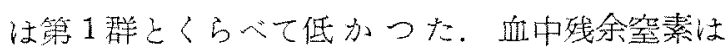
症例 70 如く $102 \mathrm{mg} / \mathrm{di}$ な上昇を示した例と症例 8，10 の如く，正常值走示多の㐫り一定の

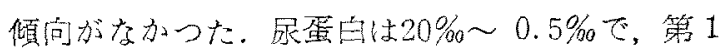
群よりは一般に高值であつた。症例10を除き浮腫

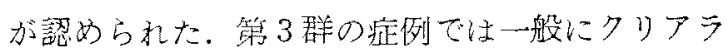
ン不值はあまり低下を慧めず，FFは0.18０.28 (平均 0.226) であった.A.I は $1.22 \sim 1.75$ （平均1.44）で血清沓蛋与像の接近を認めた。症 例11除き顕著な血尿を認的ず，又全例に円柱を

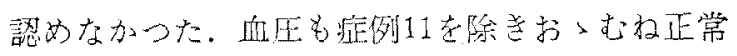
值で，血中残余絰素の增加住なく，尿蛋白は 0.3 〜 1.0\%であつた。浮嗹はほとんどの例で諗めな 认つた。

\section{3. 小括}

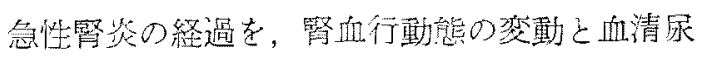
蛋白像の接近度の变動上の関係より3群に分類し た。第1群においては経過中GFR，FFの下降 


\section{渍 5. 慢桦婜炎 留機能}

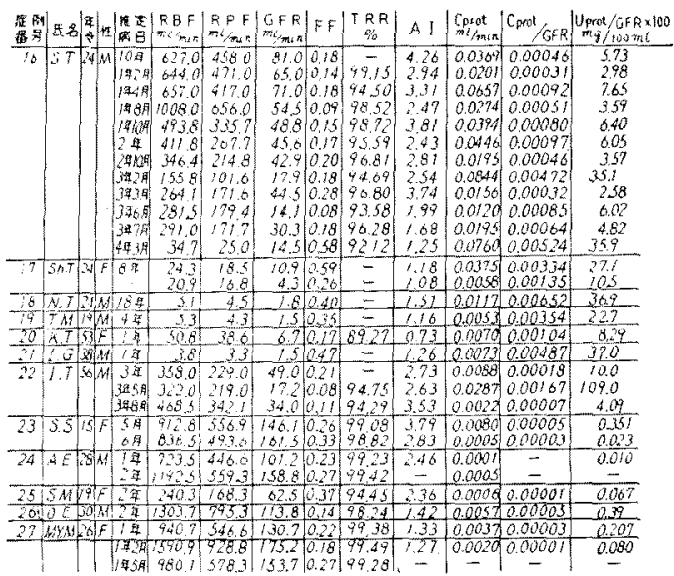

老認め，その时期に一致して血清尿蛋白像の接近 を認めた。第2 群においては経過中FFは低下世 ず，血清层蛋白像々そ机に一致して接近衣認めな かつた。第 3 羣で汶経過中FFは低下せず，しか も血清尿蛋白像は接近を認加，両者の間に関連を 認めなかつた。臨床的に㳊第1群では血尿，血压 上昇，及び全身症状がかなり目立つた。符 3 群で は一般に臨床拝状は軽汃た。

3）慢性䈌炎

1. 被秷症例

この項で取圾つた慢性腎热は，腎炎発症徭4 刃月以上を経過してはじめて槙查を開始したもの で, 経過中ネフローゼ症状を星したもの悇外し t.

\section{2. 戌緥}

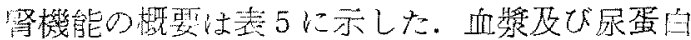

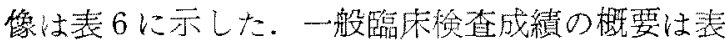
7 に示した。症例16〜2106例恃死後の剖焕によ

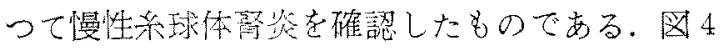
はこのうち症例16についての謷クリアランス值， $\mathrm{A} ・ \mathrm{I}, \mathrm{U}_{\mathrm{pro}} / \mathrm{GFR}$ の推移を示した。この例では 入院観察期間は 3 年以上に及んたが，GF R, F F
表 6。慢灶㲚炎 蛋白像

\begin{tabular}{|c|c|c|c|c|c|c|c|c|c|c|c|c|c|}
\hline & 篗业 & III & $\approx$ & $\underline{m}$ & 2 & 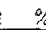 & 0 & 策 & 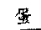 & $\underline{3}$ & 15 & & \\
\hline & 日 & $8(g / a t)$ & $A \subseteq b$ & $\alpha$ & $\beta$ & $\phi$ & 7 & $8(8 / \alpha l)$ & $A L E$ & $a$ & $\beta$ & $\varnothing$ & \\
\hline 6 & 09 & & 47,3 & & 12.6 & 11.6 & 8.3 & 0.28 & 83.0 & 30 & 7.0 & & \\
\hline & & & & & & & & & & 3.5 & & & \\
\hline & & & & & 111.2 & 8.6 & & & & 5.0 & 6 & & \\
\hline & & & & 12.2 & 140 & 4.6 & 11. & & 2 & 4.2 & 9. & & \\
\hline & & & & & & 9.4 & & & & 4.1 & 6. & & \\
\hline & & & & & & 10 & & & & 6. & & & \\
\hline & & & & & 17.9 & 8.3 & & & & 5. & 9 & & \\
\hline & 37 & 10 & .57 .5 & 13.2 & 9.4 & $7 . ?$ & 12.2 & & 0.5 & 5. & 7.4 & & 7. \\
\hline & 3 & 10 & & 1119 & 9.7 & 7.1 & 12.2 & & 8 & 2. & 5. & & . \\
\hline & 134 & & & 9.9 & 8.5 & 4.7 & 14 & & & & 6. & & \\
\hline & & & & 11.3 & 7.3 & 8.7 & & & & 5. & 6. & & \\
\hline & 493 : & 00 & & 7.7 & 9.1 & 9.8 & 12.7 & & & . & 8.8 & - & \\
\hline & $\begin{array}{l}8 \\
8\end{array}$ & & $\begin{array}{l}55.5 \\
53.4\end{array}$ & 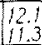 & $\begin{array}{l}9.1 \\
8.4\end{array}$ & 103 & $15 . ?$ & .25 & & $\begin{array}{l}7.1 \\
5.0\end{array}$ & 12.3 & $=$ & \\
\hline & 18 & & 54.7 & 12.2 & 12.3 & 111.5 & 9.3 & 0.20 & 71.0 & 4.2 & 13.1 & 5.0 & \\
\hline & 41 & 6.40 & 55.8 & 99 & 11.8 & 10.8 & 121 & 0.07 & 65. & $14 !$ & 10.7 & - & 8 \\
\hline & 12 & 8 & 36.2 & $\longdiv { 9 1 }$ & 7.8 & 11.0 & 369 & 0 & 33.3 & 14.9 & 14.5 & - & 37. \\
\hline & 19 & & 51.4 & 13.5 & 10.6 & 12.7 & 11.8 & 0.18 & 64.0 & 7.8 & 8.8 & 45 & 14. \\
\hline & & & 51.8 & 10.3 & 113.4 & 110.5 & & & & $\begin{array}{l}5.7 \\
58\end{array}$ & $\begin{array}{l}6.4 \\
5.8\end{array}$ & & \\
\hline & 348 & & & & 114.4 & 0.0 & & & 178.0 & 4.2 & 4.2 & 6.4 & 7 \\
\hline & 5 & & 54,8 & 11.3 & 12.1 & 9.4 & 172 & 010 & 849 & 2.5 & $\overline{6.8}$ & - & 5. \\
\hline & & & 57.7 & & 11.9 & 5 & & & 79.7 & 7.7 & 5.9 & & \\
\hline & & & 37 & & & 19.4 & & & 64.5 & 10.3 & 10.5 & - & 14.7 \\
\hline & 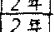 & & & ? & 64 & 7. & & & & 85 & & & \\
\hline & & & & & & 6. & 20. & & 658 & 4.4 & $1 / 3.3$ & - & \\
\hline & & & 5 & & 12.9 & 7.9 & & & 66. & & 4.2 & & \\
\hline & & & & & & 7.1 & & & & & & & \\
\hline & & & & & & & & & & & & 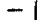 & \\
\hline
\end{tabular}

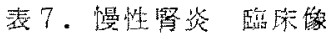

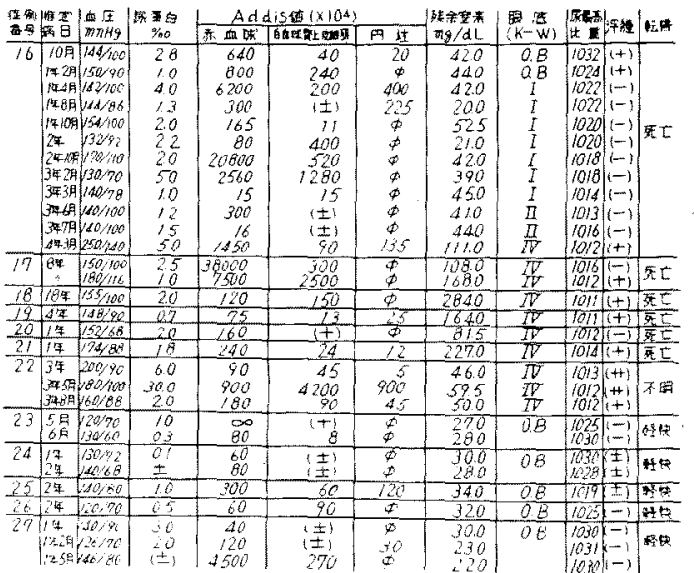

の推移々 A・I の推移は束期省除いて比較的に相

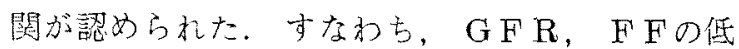
下を示す封期には，血清尿蛋白像の接近傾向が認 められた。しかし経過とっもにクリアランス值は 漸次低下を示L，GFR14.5ml/min，RPF 25.0 $\mathrm{m} 1 / \mathrm{min}$ で，FF は 0.58 示した。すなわ方，

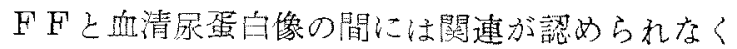
なつな。臨床的には，観察初期では尿濃縮力は正 常に近く，眼底所見にもほとんぼ变化がなかつた 名，沫期には血圧の上舁，濃縮力の減退，網膜炎 
图4.慢性系球体腎炎（姃例16）の释過

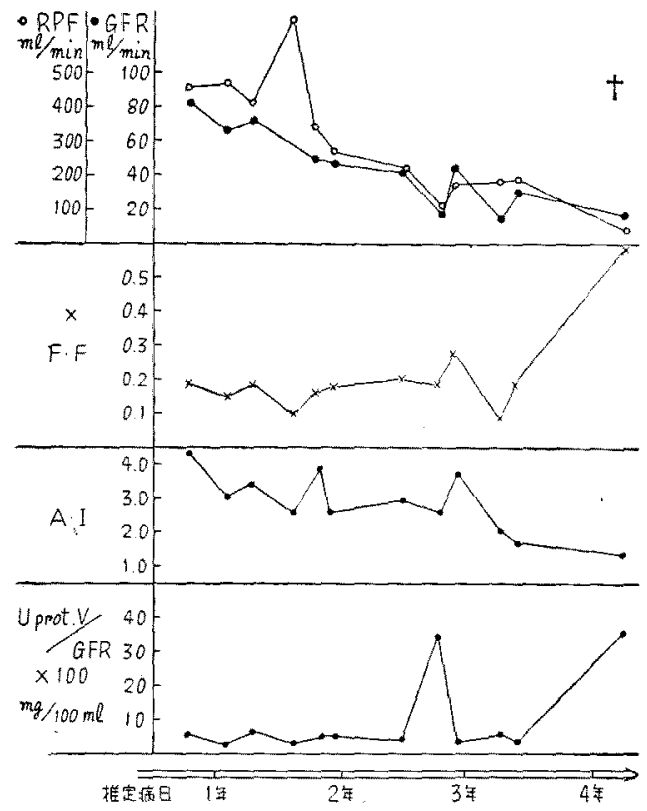

図 5. 慢性系球体腎炎末期

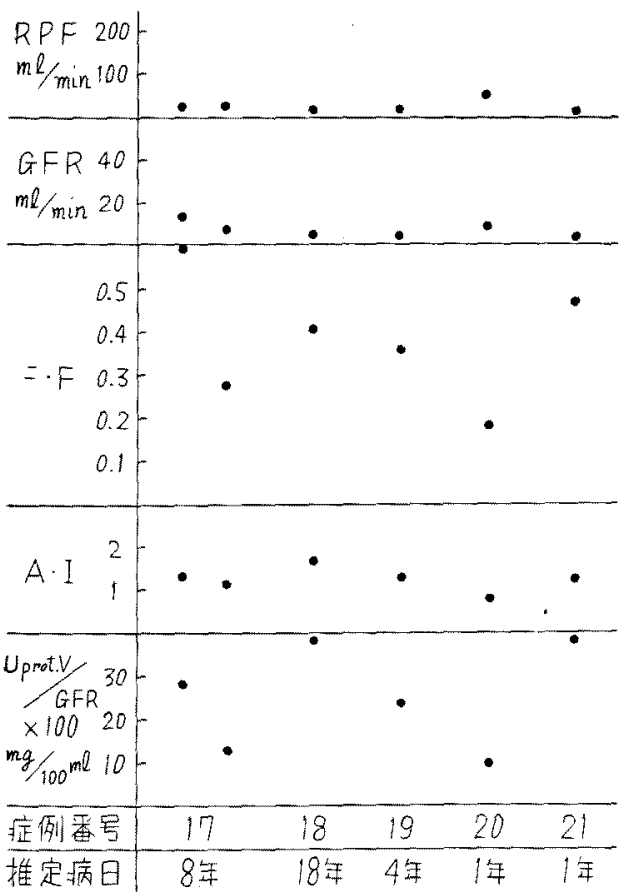

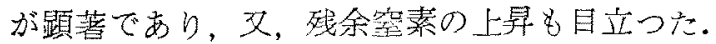

图 5 は症例17〜2105例的ついてのクリラン

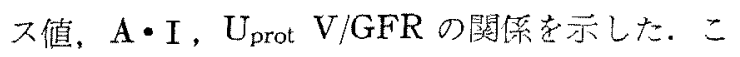

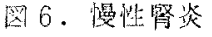

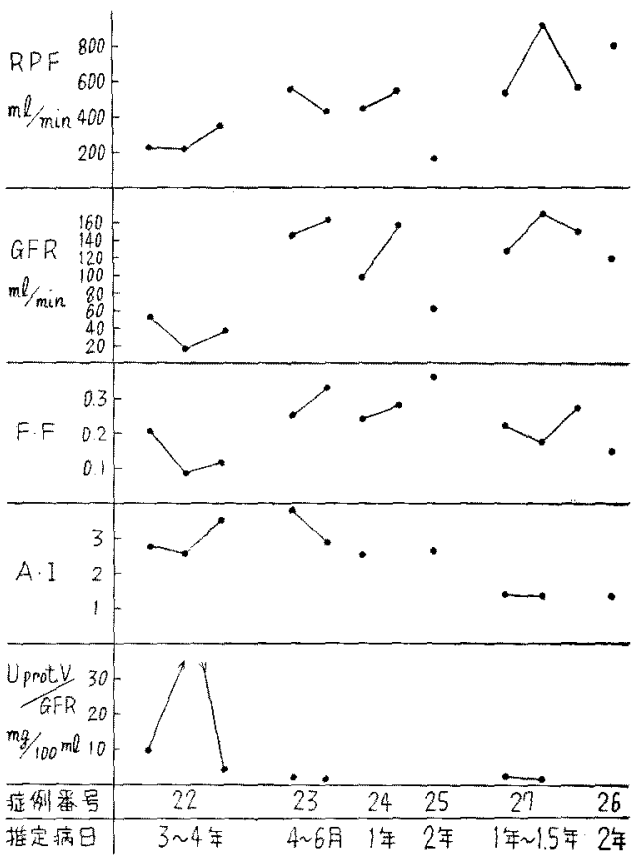

図7.ネフローゼ症候群(1) の絓過

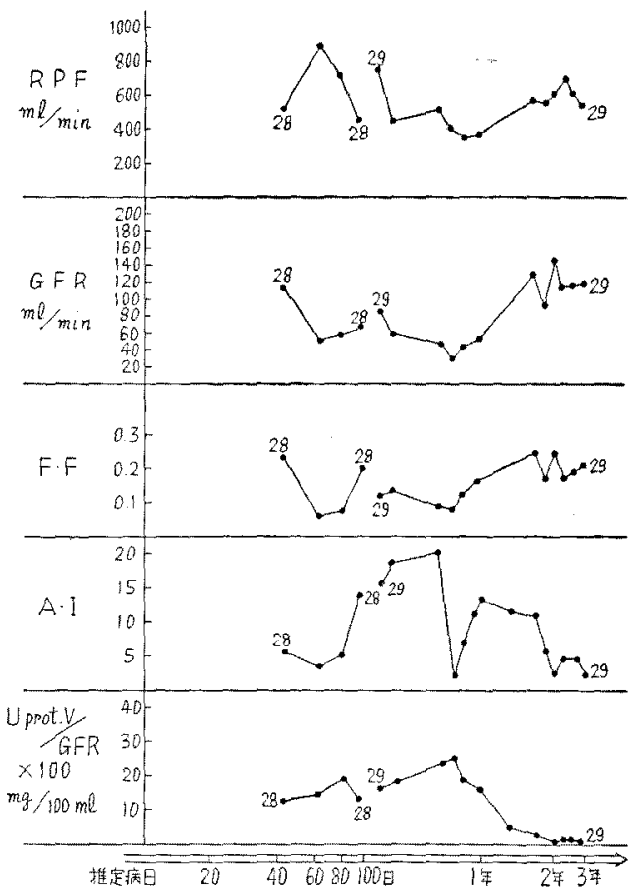

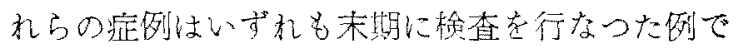

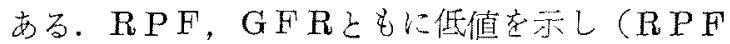




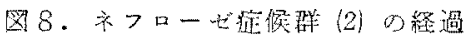

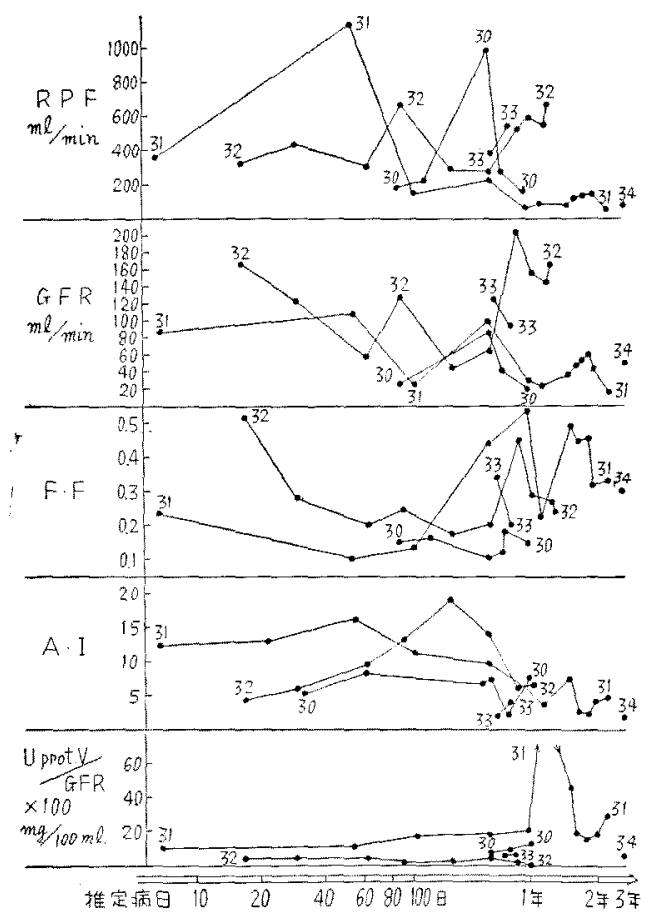

$38.6 \sim 3.5 \mathrm{ml} / \mathrm{min}$, GFR $10.5 \sim 1.5 \mathrm{ml} / \mathrm{min})$,

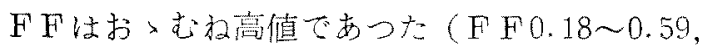

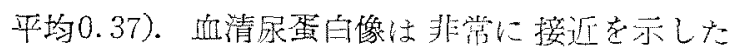

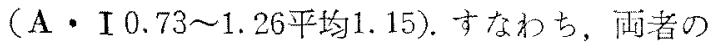
間には屓連が認かられなかつた。

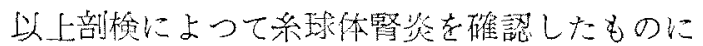

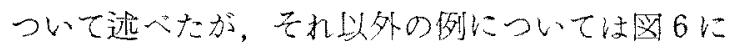
示した。症例22では観察中GFR，FFの低下の 時期に，A・I仕1に接近するの方認めた。㕛古

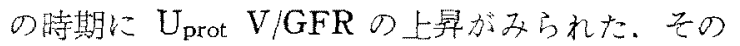

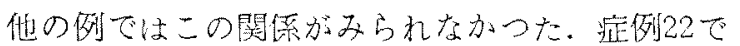

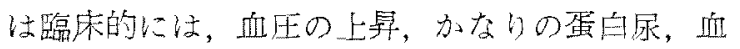

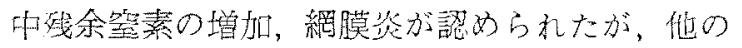

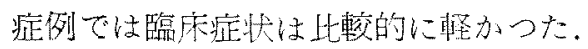

\section{3. 小控}

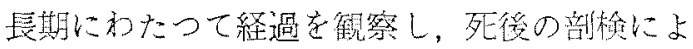

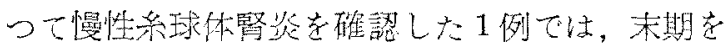

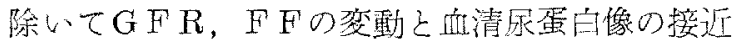

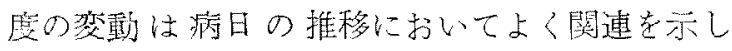

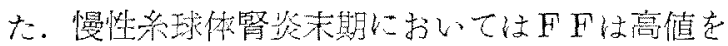

表 8.※フローゼ悰候群警譏能

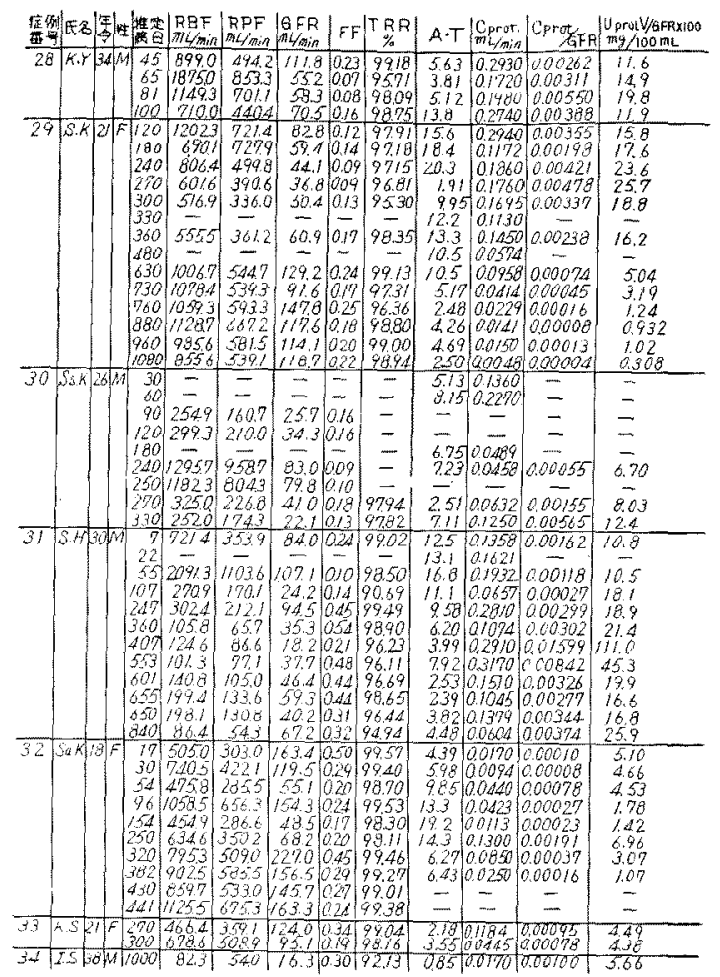

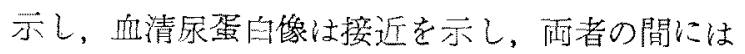
閏連汃認められなかつた。

4) ネフローゼ迹矢群

1. 被橹运邚

本項で取报つたネフローゼ症候群は，経過中主 として低蛋自血症, 低アルプミン血症, 㗬度の浮 腫, 高度の蛋白覀及び高コレステロール血症の認

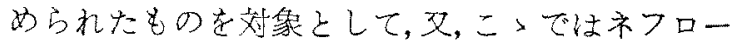

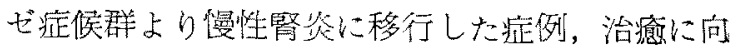
つた症例当今めて取报つた。

\section{2. 战站責}

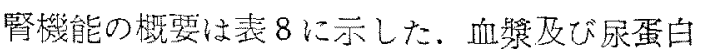
像は表 9 に示した。一般臤床检查成續の概要は袁 10に示した。哷腫，蛋百尿坴発した日をもつて

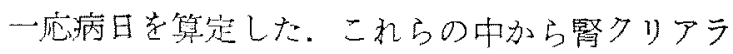
ンス值亚じにA・Iの閔係より，(1) ネフロー ゼ症候群の钼察期間のある時期にGFR， F F 低下孛認め，ほとんと同時期にA・Iは1に接近 
表9、ネフローゼ症倨群 登白像

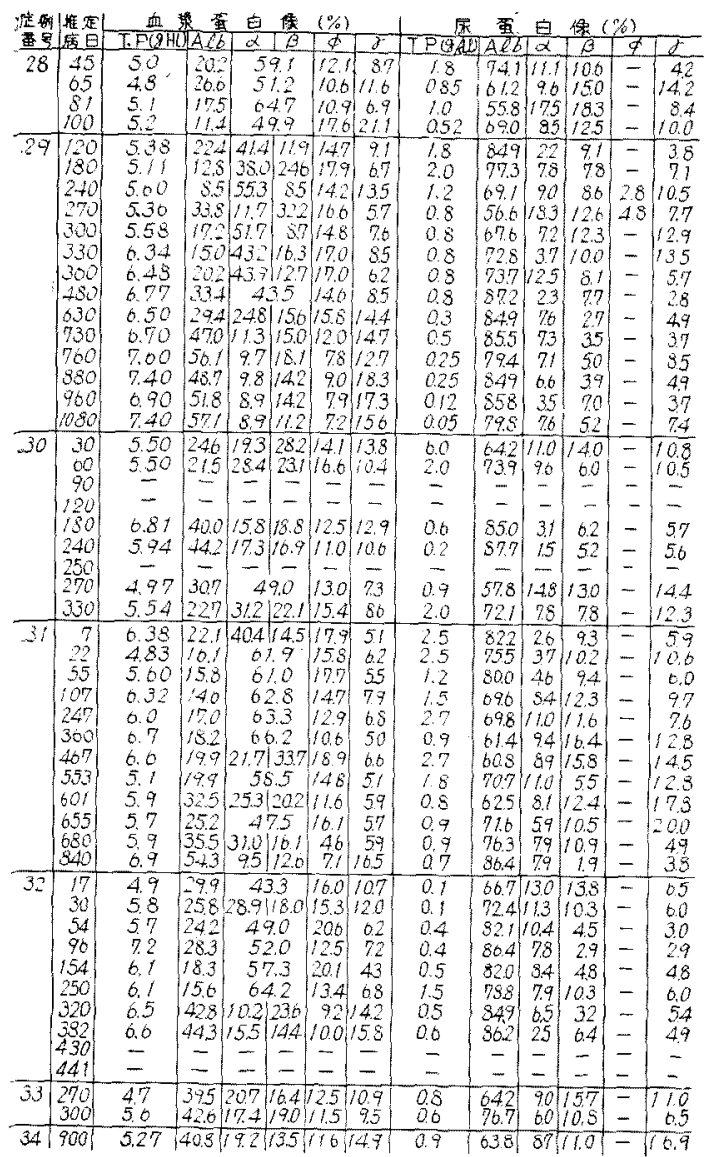

するのを認めるものと，(2) 锶祭中に上記の関 秋を認めない症例方あつた。

図7は（1）の症例（症例28，29）の婜》リア ランス值, $A ・ I ， U_{\text {prot }} V / G F R$ の推移を示し た。因に見られるように症例28，290雨例とも

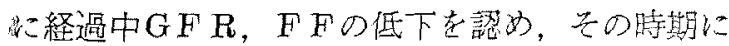
A・Iの 1 人の接近があり, $U_{\text {prot }} V / G F R の$ 增加 も同時に認吼た。図8は（2）の症例（症例 30〜34）についての腎クリアランス值， $\mathrm{A} ・ \mathrm{I}$ ， $\mathrm{U}_{\text {prot }} \mathrm{V} / \mathrm{GFR}$ の推移を示した。図に見られるよ うに謷クリアランス値の変動は病日の推移ととも にかなり著しかつた。中に洼期によりRPFが 高值を示した例（症例30，31)，GFRが高值を示 した例（症例32）があつた。FFが経過中低值を

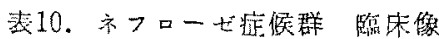

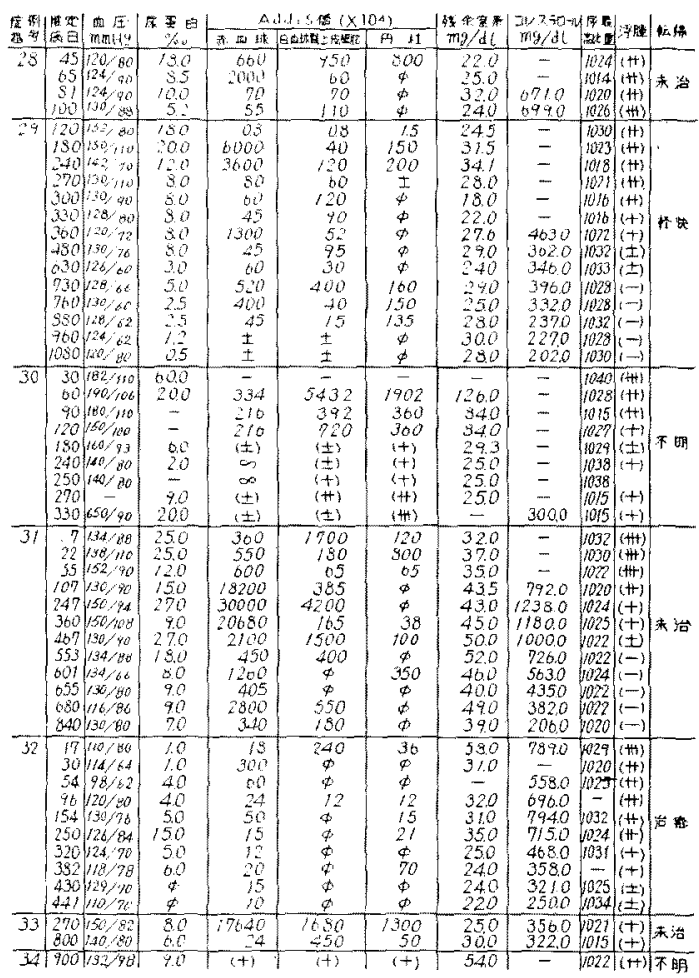

示しな時期にもA・Iは1への接近傾向認めな かつた。慢性腎资八移行した例では，フリアラン 又值は低下し，A・I住1 几接近定示した。臨床 的には（1）の症例（症例28，29）では，FFの 低下のみとめら狆た時期に，尿有班成分殊に赤血 球の增加加一致して諗められた。症例29ではこの 時期に血王の上昇が認められた。（2）の症例で は, 症例32では経過中血原の增加及げ血王の上昇

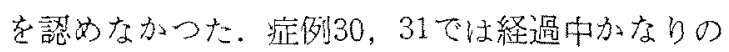
血尿，血王の上昇を認め，症例30では経過中残余 空素の加なの增加があつた。

\section{3. 小括}

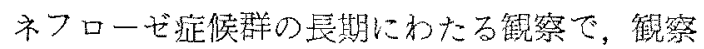
中（1）GFR，F F の低下する洔期に血清㲾蛋 白像の接近を示卞症例艻あつた（2）又この䦙 係の認められない症例当あつた（1）の症例に おいては，臨床的には F F の低下時に一致して血 尿の堌加を認めた。 


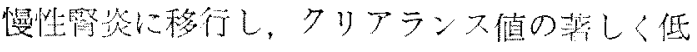
下した例では血清家雷白像り接近索示した。

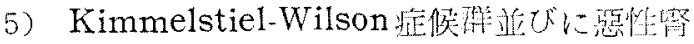
硬化症

1. 被顺淀例

惡性婜硬化症の1列（症例36）を除き，死後の 剖松にて診断を確諗したものである。

2. 成縚

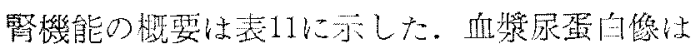
表12に示した。一般臨床模查成續の概要は表13に 示した。 Kimmelstiel-Wilson 症俟群の1例に おいては，死の直前までRPF，GFRとも潫次

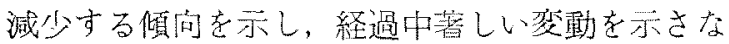
かつたＦF注経過中低值を示さなかつた，死の 直前フリアランス值の著しく低值を示した時期

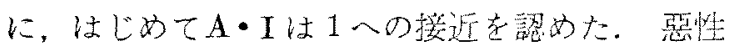
腎硬化症の死亡した2例では，クリアランス値の 低下は藷しく，血清尿蛋白像はかなりの接近老認 めた。

6）剖梌例に打叮る成續子縕織像

こっでは郎に記速した症例も含まれるが，剖枪 により死後䛦断を確認した急性系球体留炎2例， 慢性系球体婜炎 7 例，ネフローゼ定做群，Kimmelstiel-Wilson 症候群 2 例, 惡性腎硬化症 4 例 について述へる。血漿及び尿蛋当像，A・I，お よび腎クリアランス值については嬉14に示した。 表にみとめられるように，クリアランスを行なつ た症例では，RPF，GFRとともに兓述の如？
非常に低值を示した，A・Iはネフローゼ症候群 では15.4, 急性系球体腎炎では2.62〜2.42(平均 2.52), 惡性腎硬化症では2.02 1.41 (平均1.63), Kimmelstiel-Wilson 症候群では1.22〜1.14 (平 均1.18), 慢性杀球体腎资では 1.51〜0.73 (平均 1.12)であつた。すなわち以上の疾患の順序で， 血清尿蛋白像の接近認如た。の内症例39(ネ フローゼ症候群)，症例41 (急性系球体腎炎), 症例 43 (惡性緊硬化症), 症例36 (Kimmelstiel-Wilson 症候群)，症例16 (慢性杀球体謷炎) の系球体 病変の組織棛について因 9 に示寸（本院派辺によ る). 主な組織所見党記すと，

症例39：糸球体には殆ど見る心き変化がな い. 方なわ貢底膜もzartで，核の增加もない。 症例41：結合織細胞の強い堌殖のため, 系球 体の“富棪，膨隆，筫血”が著明である。しかし 6才の小見であるから糸球体の大きさはわりに小 さい。

症例43：基底膜怯症例39に比して，明らかに 肥曆している. 症例16，症例 36 とくらべると遥加 に zartて正細管柔踩の走行もよく制別し得る。 左上部に楾維素の折出を伴なう結合織細胞の增殖 をるる。

症例36：Mesangium は硝子性又は線維性に 強く肥厚し，以わゆる結節性の肥厚を呈す。

症例16：右半分侍永い間の透過性の六進の結 果, 線維性に肥厚し、毛細管柔蹄の走行は制別し 難い。左半分では采踇の走行が乱れ，被覆上皮の

型11. Kimmelstiel-Wilson 症侯群

掔 機 能

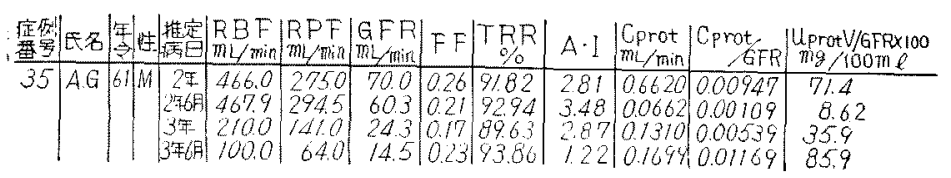

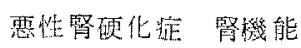

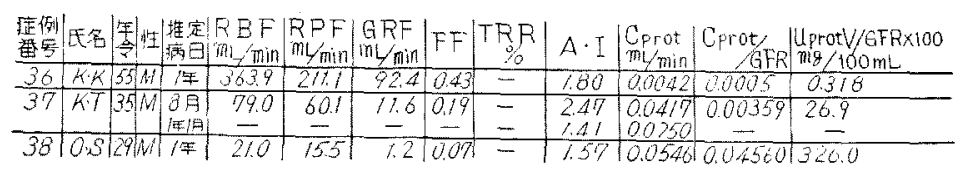


表12. Kimmelstiel-Wilson 症噼群

蛋白鳋

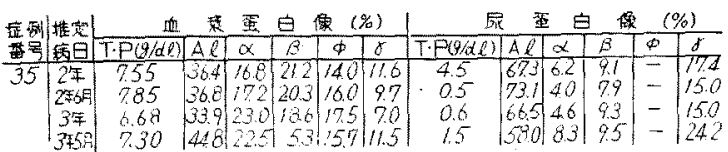

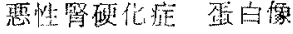

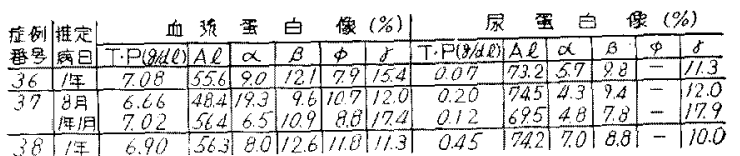

表13. Kimmelstiel-Wilson 症候群

踥 床 像

\begin{tabular}{|c|c|c|c|c|c|c|c|c|c|c|c|}
\hline & 助 & 家蛋白 & Addi & $(\times 10$ & & & & 眼承 & 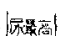 & & \\
\hline & 日 $\mathrm{mm}$ & $\%$ & 赤血球 & 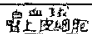 & 丙柱 & $\mathrm{mg} / \mathrm{dl}$ & $m g / d !$ & & & 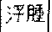 & 较慢 \\
\hline 35 & 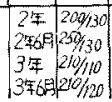 & $\begin{array}{r}45.0 \\
50 \\
6.0 \\
150\end{array}$ & $\begin{array}{r}50 \\
120 \\
5280 \\
80\end{array}$ & $\begin{array}{l}2500 \\
2400 \\
2480 \\
3200\end{array}$ & $\begin{array}{c}100 \\
240 \\
420 \\
4\end{array}$ & $\begin{array}{l}37.0 \\
40.0 \\
525 \\
67.0\end{array}$ & $\begin{array}{l}4500 \\
570.0 \\
9120 \\
950.0\end{array}$ & $\frac{\pi I}{\frac{I I}{I I}}$ & $\begin{array}{l}1022 \\
1017 \\
1017 \\
1015\end{array}$ & $\mid \begin{array}{l}1+1 \\
(+t) \\
(++) \\
(t+1)\end{array}$ & $\bar{x} t$ \\
\hline
\end{tabular}

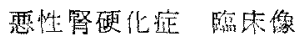

\begin{tabular}{|c|c|c|c|c|c|c|c|c|c|c|c|c|}
\hline & 梅定 & & $0 x$ & Ad & Sig $\times 10^{4}$ & & & & $6 x$ & & & \\
\hline & 病目 & $\mathrm{H}$ & $\%$ & 赤而球 & 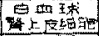 & F 桂 & $\mathrm{mg} / \mathrm{dL}$ & $m 9 / 0$ & 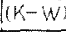 & 让電 & & 䎐趃 \\
\hline & 2 年 & $170 / 24$ & 0.7 & 144 & 160 & $\phi$ & & $E$ & $\pi$ & 1021 & $(+1)$ & 喜社 \\
\hline & 89 & $\begin{array}{l}20 / 160 \\
246 / 156\end{array}$ & $\begin{array}{l}20.0 \\
12.0 \\
\end{array}$ & 71 & $\begin{array}{r}81 \\
592\end{array}$ & $\begin{array}{c}64 \\
\$\end{array}$ & & - & $\frac{I V}{J !}$ & $\begin{array}{l}101 \\
101\end{array}$ & $\begin{array}{l}(+1) \\
(++)\end{array}$ & Dat \\
\hline & 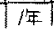 & & 45 & 4800 & 840 & 60 & C & 328.0 & 77 & $1 / 1013$ & $T(t+)$ & 19t t \\
\hline
\end{tabular}

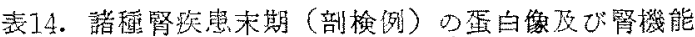

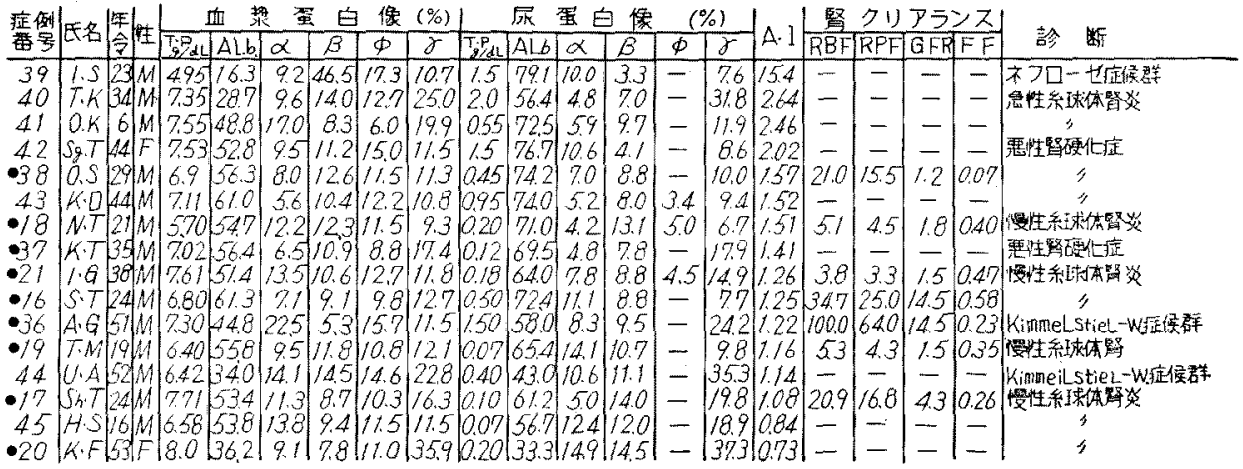

-眇述

增殖著明である。な抄大多数の糸球体の変化は更 に高度で硝子様の球と化している。

\section{IV 考案並ひに総括}

腎疾患に扔いて，系球体病変の障害の程度は㹂 疾㭧の病型，病期等によって当然異疗るものと管 えられるが，二れを臨床的に把握することは重要 なことと思われる。通常われわれが腎焱の症状と して観察している血原，蛋白康，血压の上䄯，浮 腫等の臨床所見も，これのみについては，筲病変 中に招ける系球体病变の占める，比重を制定する
ためには一義的の意味での重要さはないと思われ る。腎クリアランス法によれ将，GFR，FFの 低下注糸球体機能の低下を意味寸るぶ，腎クリア ランス法は正常腎についての理論に基づくもので あり，これを病的腎倍通用してその系球体病变の 程度老知るため沈は，二れと原理索異にする方法 を併用してその妥当な範图を経験的に知る必要が ある。そのため今回は血清杘蛋白像の接近度を測 定して，この問題の檢討を行なつた。一般に血管

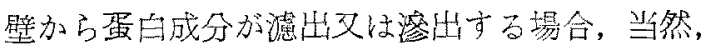


図 9

症例39ネフロービ症候群

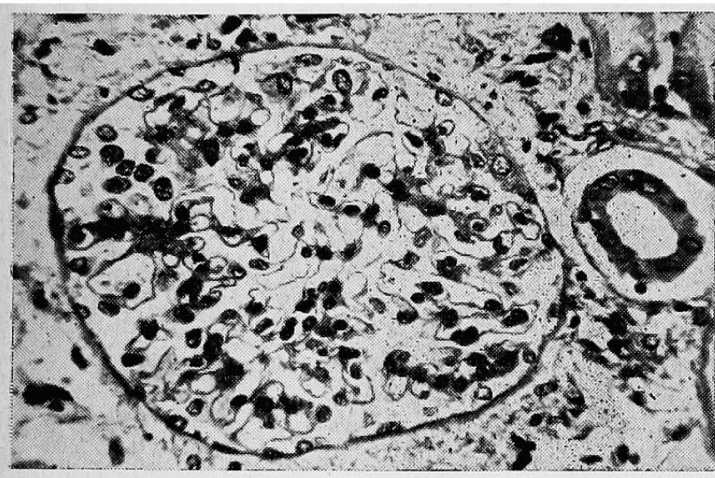

症例41 急性系球体腎炎

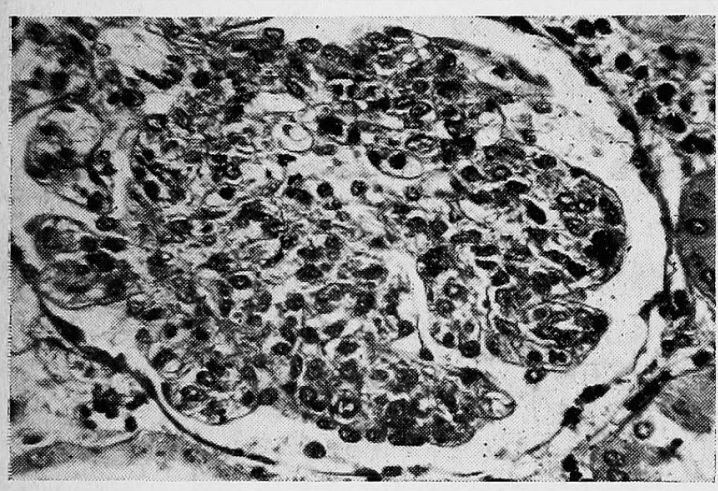

症例16 慢性系球体腎炎

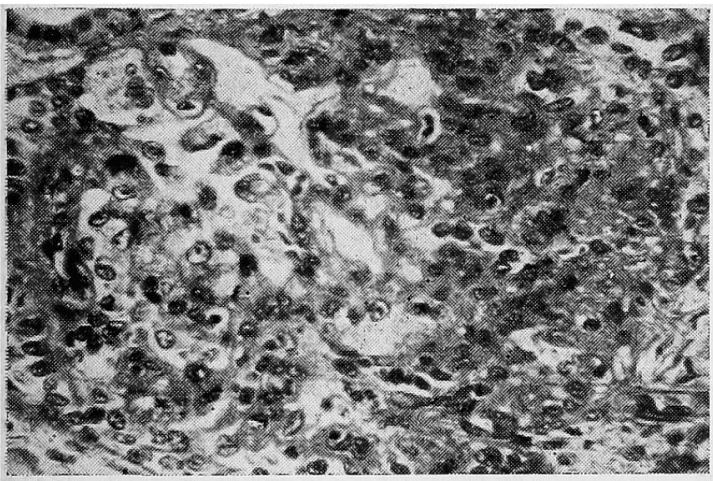

蛋白分㡈中の分子量の小さいものほぼ血管壁の通 過が窄易であることが考えられ，事奏, 肋膜炎, 䀒 硬変，火賃等の滤滲出液と血墏の間，又は母体と 胎見の血獎の間にも証明されているここである。

すなわち滲出液の場合, 沙出液の蛋白像がその血 蒗の蛋白像に接近を示したときは，その血管壁は 分子の大きな蛋白分屑をも多く通過させたことと
症例43 覀性留硬化症

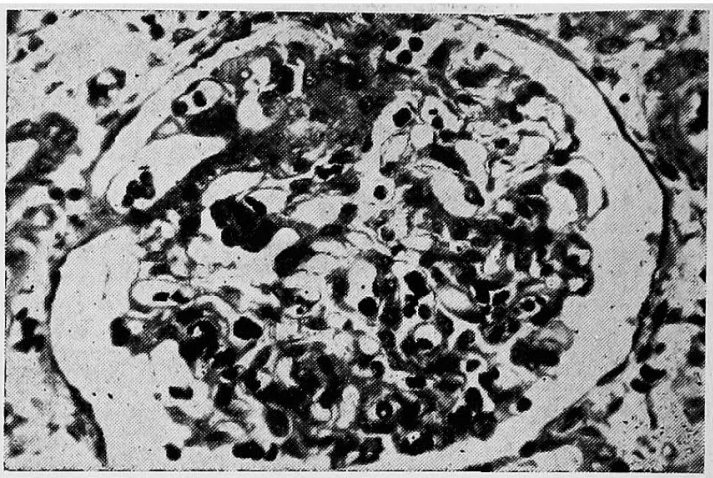

症例36 Kimmelstiel-Wilson 症候群

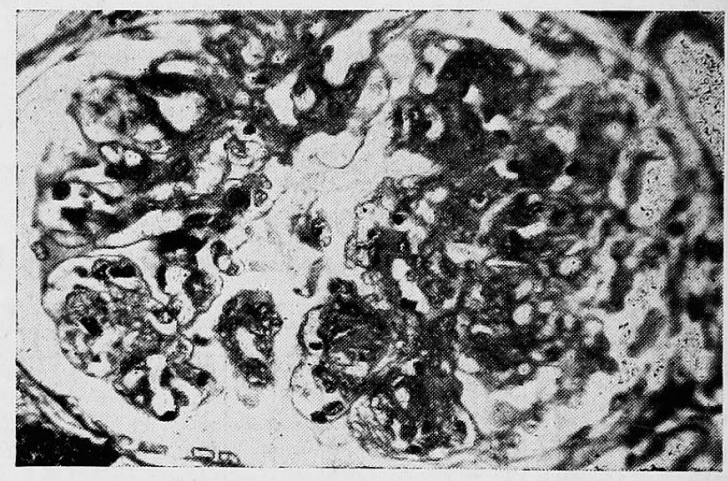

なり，その血管壁の蛋白透過性は元進したと解釈

することが出来る。本研究で用いた血清尿蛋白像 の接近度の計測は，腎における尿細管の蛋白分局 の再吸收它全〈無視するか，全く平等の割合で尿 細管で蛋白分㾓の再吸收が行なわれるか，又は同 一症例についてその経過の変動での蛋白の再吸収 の条件が大きく変らない限り，糸球体毛細管の蛋 白透過性を示す一つの方法であると考えられる。

しかしこの際禾球体滤液中の蛋白質が，細尿管通 過中心かなる処置を受けるから問題となる，尿細 管の蛋白再吸収の研究は多くあるが，Gérard $\left.{ }^{8}\right)$ が蛋白再吸収能を有することを泟明して以来, Dock, Gilson, Smetana の研究, Oliver らの 研究があり，又， Sellers ら ${ }^{9)}$ は腎動脈血，下空 静脈，腎静脈より同時に採血したアミノ酸空素及 びポリペプチッドの差から再吸収量を測定してい る. 山内10)もこの方法により，病的腎では正常腎 にくらぺて再吸收量は少ないと述べているが，現 
今このことを無視出来ないとされている. 㕛分于 量の小さな蛋白分屋は大きなも的より，より多く 吸收されるということ神を考えると，直ちに血清 康蛋白像の接近度より注系球体焉白透過性を諭じ られないが，同一症例の経過を追究する場合，尿 細管に㧍计る蛋白再圾收の条件が大きく变らない 限りは，その経過での系球体の蛋当透過性を推察 出来るとの立場で，令回はこの方法を猝用してみ た。したがつてこの場合，経過中尿蛋白像が血清 蛋白像に接近することは，系球体毛細管における 蛋白透過性の克進を意味する。次に各疾㭧につい て述へる。

すでに急性糸球体腎焱についての腎血行動熊の 研究情数多くあり，その特色乙してGFRの低下 とFFの下降をあげている。私の急性腎炎の成續 で,第1群に分類したものは, 経過中著しくGFR とFFの低下を認めた。クリアランスの理諭によ れば，FFの低下は亲球体機能の低下を意味す る。このFFの低下の时期に一致して，血清尿蛋 白像の接近が諗められた。血清尿蛋白像の接近は 系球体蛋白透過性の充進を意味するので，二の而 法で同時に相関が䜑められたので，二の群に属す る症例の留病変中心占的る杀球体病変の此重注, 重いものと考えられる, 症例 $3 ， 402$ 例は, 猩 紅熱欴染後におこつた猩紅熟腎炎であつた。この 腎炎は以前加亲球体腎㶤であるといわれている 加，私の成績から見ても，この第 1 群に属古る症

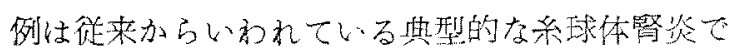
㐫ることが推定される。第2群に䙓した症洌は， 腎炎経過中あまり F F の低下を譛めず，かつ，蒛し 以血清尿蛋白像の接近同时に認めず，このこと から第 2 群に属する症例て，婜病变中心占以る系 球体病変の比重は軽いものと考えられる。第了群

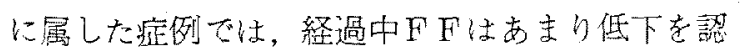
めなかつたが，血清尿蛋白像法かなりの接近を缕

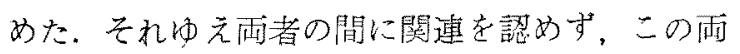
法のみから考无れば，腎病变中に占める系球体病 変の此重を決定することが出来なかつた，徒来加 ら腎炎の分類は多くの学者によつて試みられて来
た。我が国では昔から，Volhard 及び Fahrの 分類吕多く用いられている。 Longcope ら ${ }^{12}$ 急性蜸资を2 群に分け，彼のいうA型のものは， 早期の症状法通常の采球体腎炎に一玫し，先行 主る感染についで掩病し沿痛率は高く，B型のも のは発病は潜行性で浮腫を主徽上するものが多 いと速いている，Ellis ${ }^{13)}$ 女系球体腎炎を 2 型に 分け，二つの買疗疾患として，I型腎炎，II型 腎炎に分類している。I型は発病は突然におこ

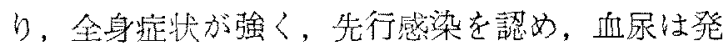

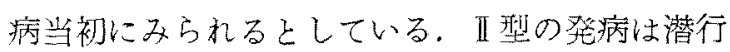
性であり，全身症状は軽く，血尿は少なく浮腫 を主徴とするといつている，その他Van-Slyke， Addis, Christian, Frey 等, 多くの者分分類を しているが，通钼してみとめられることは臨床的 にも，病理学的にも良来加らい任れている糸球体 留炎の範围の报い方には，加なり不明膫な点が存 在することである。諏訪年は腎炎を循環障害の立 場加方，系球体腎炎已間質性腎炎と红病理解剖学 的に分類している。系球体腎焱ではVas afference の収縮效果が 主に系球体に強い变化をおよば し, この場合比较的尿細管の変化は軽々，間質性 腎炎では太い動服枝の収縮効果で尿細管の変化が 強く，この場合系球体の变化屿軽いと述へてい る。元して系球体腎炎と間質性腎炎の間には移行 型の存在を述べている，私の第 2 群に属した症例 は杀球体病变の程度が第 1 群に比して軽く, 経過

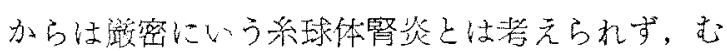

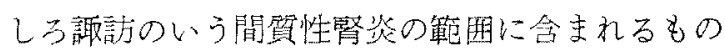

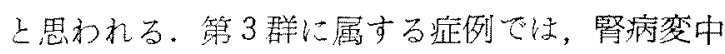

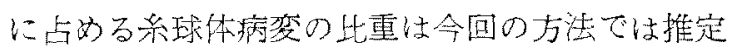
出来なかつたが，乙の解明山今後の間題であると 思われる，文，臨床的にかなり血屁の観察された 症例でも，蕃者の今回の方法で，杀球体病変の程 度の僌い々推定された例のあつたことは興味ある こと>思われる。

慢性系球体繁炎の末期に㧍いて，FFの䯩值 を示すことは，多くの研宽で明らかなことであ る. Cargill はGF Rが $60 \mathrm{ml} / \mathrm{min}, \mathrm{RPF} か ゙ 300$ 
$\mathrm{ml} / \mathrm{min}$ 以下に低下寸ると，パラアミノ琵尿酸ソ 一ダ除去彎が減少し，われわれが通常の方法で测

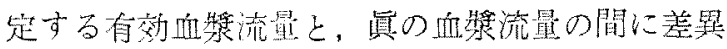

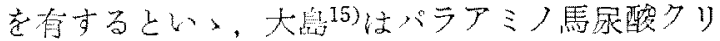
アランス値が皮祭よりも小さな値をとり，このこ とはF F の意義导考える場合注意を要すると逝心 ている，私の症例に扔いても，慢性希球体紫炎末 期の症例ではRPF，GFRともに低值を示し， F F 核高值を示した，血清尿蛋白像は著しく接近 を示した，血清尿蛋白像の接近は系球体蛋白透過 性の亢進を譩味するので，FFのこの上舁につい ては以上のパラアミノ馬尿酸クリアランスが少さ な値を寿際よりとるか，又は短絡等についても一 若する必要があり，フリアランス法の要求する腎 の生理的条件に合致しなくなるものと考无られ る。症例16で見られるごとく，倠察初期から中期 にか忖ては，GFR，F F と血清尿蛋白像の接近 度がかなり相関していたこと，すなわち杀球体機 能と系球体蛋白透過性の間にある程度関連が認め られたが，次第に病日の推移をともに，GFR， RPF全般の䔔しい低下を来たし，F F 2 血清尿 蛋白像の接近度の間に全く関連が虫められなくな つたことは，孯フリアランス値の解釈の一つの限 界を示すもの上思和る。

ネフローゼ症候群についての腎フリアランス值 は，既に多くの報告があり，その特色として巾広

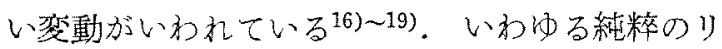
ポイドネフローぜ型では，正常及は正常以上の值 を示すが，ネフローゼ症候群の大部分の症例では クリアランス值は正常以下を示すという. Bruck

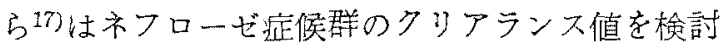
し，本症候群では同一症例について長期にるたつ て変動を追跡しなければ，その様相は厺分に把 握出来ないる述へている。元して糸球体腎炎を伴 なうものでは，経過中GF R，FFの低下と血尿 の存在をあげている、私の長期にわたつて観察し た症例において，症例28，2902例では観察中 GF R，FFO低下する時期にほとんど一致して 血清尿蛋白像の接近が諗められたことは，ネフ
ローゼ症候群の経過中に糸球体病装の增惡期を証 明したことと拷えられる。この時期には臨床的に は血层の增加が認められた。, 又, $\mathrm{U}_{\mathrm{prot}} \mathrm{V} / \mathrm{GFR}$, $\mathrm{C}_{\text {prot }} / \mathrm{GFR}$ むこの時期に上昇肪認められたこと は，以上のことを更に裏暗きするものといえよ う。他の症例（症例30 33）ではF $\mathrm{F} の$ 低下時 に，血清尿蛋白像の接近が認められなかつたこと 加ら，症例28，29で意味するような沉系球体障害 を推定出来ないと思和机る，页》リアランス值加 ら見たネフローゼ症候群の大部分の症例では，病 日の推移と共に著しく血行動態が変化した。それ 故，ある任意の時期の像からは，ネフローゼ在候 群の特色を規定することは㤕来ない。三輪ら20》は 本症候群のフリアランス值の変動について，本症 候群の機能障害に注機能的可迹異常，浮腫等の影 蓺が相当の比率で加かることの可能性を述へてい る.以上のことから，臨床的にネフローゼ症候群 を示寸例の腎の病変そのものは單一でなく，種々 のちがつた䩹の過程が，臨床的には共通の症候群 を示し得るものであることが理解される。中には 血尿, G F R 下下降，F F の下降，血清尿蛋白像の 接近老同時に示した例があつた。これによつて経 過中系球体病変增惡期を見出すことが出来たが， クリアランス值, 血清尿蛋白像の接近度の諸要案 を別々に見ると，その变動に対しては現在の段階 では必ずしも明らかな意味を与えることは出来な い場合が多い之考えられる，又慢性腎炎に移行し てRPF，GFRが著しく低下した場合，これに 血行動態的解釉を与えることは不可能と考えられ る。

Kimmelstiel-Wilson 症候群のクリアランス值 については Robertson は諸機能の著明な低下を 認めたが，本症特有なものは発見出来ず，慢性腎 炎との鑑别は困難であるという。

Rifkin は一般にF F の低下を述ぺ, Corcoran は23\%の症例にF F D上开認め，一般には RPF， G F R ともに低下を示すと述べている. 私の経過を観察した1例では，クリアランス値は あまり变動なく激次低下を示し，FFは低下を示 
さなかつた，贠血清尿蛋白像の接近も未期を除き 著しくは諗的行ず，これらのことから経過中に 今回の方法では, 系球体病帘の增琵期索推定出来 なかつた。惡性㹂硬化症のクリアランス値につい てはRPFの減少がいか子，又FFの高值を示主

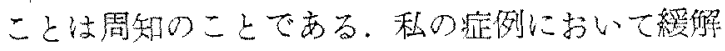
した1例を除き，いずれも末期の例であるので， 婜の破壞が著しく血行動態上血清尿蛋白像の接近 度の間には闇連が諗められなかつた。

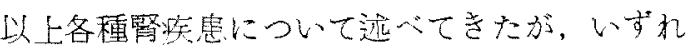
の疾患でも末期においてはクリアランス值は非営 に低值を示した，死後剖梌によつて診断を確認し た例では，血清尿蛋白像の接近度の成績加らその 禾球体毛細管蛋白透過性の順序を比較すると，ネ フローゼ症候群，急性系球体筒炎，惡性腎硬化 症, Kimmelstiel-Wilson 症候群，慢性系球体 蜸焱の䐓であつた。このことはわれわれの例での 組織学的の糸球体病变の程度の所見と較べておお 上そ一致するので, クリアランス值が末期に㧍い てクリアランス法の要求する生理的条件に合顼し なくなったために，正確学管病変中心系球体病变 を示さなくなるに反し，卆のような場合でも血清 层蛋白穆の接近度は, な纱系球体病変の程度を示 す有效な指標となり得ると考えられる。

以上主として各種蜸疾患に予ける糸球体病変の 比重を臨床的に決定することを試みた。もち万 ん, 現在では直接腎生检で病理組織学的にこれを 決定することは可能であろうが，同一患者につい て，その变動を追究することは多くの制約を受け る、徒来，堅疾患の病態像を見る場合，断面の集 積でその疾㭧の表現をする傾きもあつたが，今回 はつとめて同一症例においてそれぞれのその変動 を知ろうと試みた。今回の成續からみれば，堅病

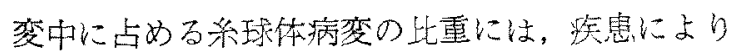
かなりの差異肪みられ, 又, 同一症例でもその経 過中糸球体病変の程度にかなり段階のあることを 知り得たと思预れる。

\section{$\mathrm{V}$ 結 論}

諸種腎疾患45例について, 腎クリアランス法に
よる緊血行動態の䐿查 121回，Tiselius 法によ つて血潜尿蛋白像の接近度の測定を118回行ない，

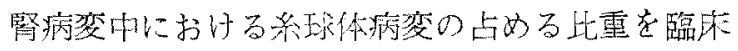
的に刵定するこ上老試み，次の結論を得た。

（1）㫮誒㭧中にはクリアランス法で示される 系球体機能と，血海层蛋回像の接近度で表方され る杀球体蛋白透過性が相閵する症例方ある。この 闭法で相関する範阘においては，婜病変中に占め る糸球体病变の比重を臨床的に制定し得るものと 思和机る。

（2）急性腎炎の中には，i）経過中GFR， FFの低下の認められる時期に，両蛋白像の接近 の認动られる症例がある。この群に属するもので は糸球体病変の占める比重が大であり，典型的な 猩紅熱㹂炎もこの中に含まれた。 ii) 経過中F F は低下せず，及，息蛋白像の接近を認めないもの もあつた。この群では杀球体病変の占める比重は 軽いものであることが推定される，iii)而法にて 関連の認められないものもあり，この群に属する ものの解朋は今後の問題である。

（3）慢性系球体婜炎の末期の症例では，F F は高値を示し，血清家蛋白像淁近を示した。こ れは腎の破買方菇しく、クリアランス法の要求す る生理的条件に合致しなくなつたものと考えられ る。

（4）かなり長期にわたつて䚁察したネフロー セ症候群の中には，経過中の一封期に GFR， F Fの低下と，血清瓜蛋白像の接近と，血尿の増 加が同時に垫められたものがあつた。このことよ りネフローゼ症候群の糸球体病変增惡期を臨床的 に推定出来た。

（5）剖橡によつて䛦断を確諗された諸種腎疾 患の末期の列て，血清尿蛋白像の接近度を此較す るとネフローゼ症侯群, 急性糸球体謷炎, 惡性腎 硬化症，Kimmelstiel-Wilson 症候群および慢 性系球体腎炎の順で接近を示した。クリアランス 值が著しく低值を示し，クリアランス法の要求す る腎の生理的桑件に合顼しなくなつても，な扔血 清原蛋白像の接近度で示される糸球体蛋白透過性 
は，杀球体病変の程度を知る指標となり得るもの と考えられる。

（本研究の要旨は符55回，第57回日本内科学会総全潮 演会に打いて哞表した.)

\section{主要文献}

1) Smith et al: J. Clin. Invest., $17: 263,1938$. -2) Welker et al: J. A.M.A., 86, 1388, 1926. $-3)$ Giltlin et al: J. Clin. Invest., $31: 223$, 1952. -4) Widdowson: Cit. in " Biochemistry of Disease" by M. Bodansky and O. Bodansky 2nd. Ed. p. 218, 1952. - 5) Bing: Studies on Proteinuria "Albumiuria" acuta med. Scandinav., Suppl. 76, 1936. -6) Chinard: J. Clin.
Invest. $33: 621,1954,-7)$ McGarry et al: J. Clin. Invest., 34, 832, 1955. - 8) Gérard: J. Anat. 70, 354, 1936. -9) Sellers et al: J. Exp. Med. 101，129，1955，一10）山内：日大医 学誌, $17: 11,2177,1958$. - 11) Spector: J. Path. and Bact., 68, 187, 1954. - 12) Longscope: J. Clin. Invest. 15, 282, 1936. -13) Ellis: Arch. Int. Med. 84, 159, 1949, 一14) 㑔訪: 最 新医学, $10: 3,10: 4,10: 5,10: 10,1955$. 15）大島：日内誌，46:8，1957。一16) Bladley: Am. J. Med. $9: 766,1950 .-17)$ Bruck: J. Clin. Invest. 33:699, 1954. 一18) 宇丼: 千医会誌, $33,1236 ， 1958 .-19)$ 上田, 他: 日本臨東，14:34, 1956. - 20) 三輪, 他：日本臨床, $16: 1389,1958$. 